\author{
綾部協立病院外科 \\ 十倉 正 朗川嵉繁
}

膵十二指腸動脈嘴は比較的珍しい疾㭧で，感染や膵炎，動脈硬化等以外の約半数が腹 腔動脈根部閉塞や狭窄が原因とされている，上腸間膜動脈血流が大量に膵十二指腸動脈 を経由し腹腔動脈系へ流れること, 動脈の脆弱性も加わることで動脈瘤が発生すると考 えられている.われわれは腹腔動脈根部閉塞を伴わない膵十二指腸動脈瘤症例を経験し た。動脈瘤と拡張した膵十二指腸動脈の塞栓により同動脈は正常に近い太さに回復, ま た arc of Buhler の塞栓にて上腸間膜動脈から腹腔動脈系へのシャント血流が消失し た. 以上より, arc of Buhlerによるシャント血流で上腸間膜動脈と腹腔動脈の圧格差を 生じ, 膵十二指腸動脈に压と血流増大の負荷が加わり, 動脈は拡張し動脈瘤が発生した と考えられた。治療上 arc of Buhler の遮断と膵十二指腸動脈瘤の塞栓が必要と考えら れ，IVR は非侵襲的で有効な手段と思われた。

索引用語：膵十二指腸動脈瘤, arc of Buhler, 腹腔動脈非閉鎖

はじめに

膵十二指腸動脈瘤 (以後 PDA-A) は感染や膵炎, 動 眽硬化等以外では主に腹腔動脈 (以後 CA) 閉塞や狭窄 が原因となり発生すると考えられている.今回われわ れは CA 根部に狭窄や閉塞はなく, arc of Buhler（上 腸間膜動脈と腹腔動脈根部を直接吻合する動脈）が動 眽瘤発生に重要な役割を果たしていたと考えられる症 例を経験した。治療ではマイクロカテーテルを用いた 動脈瘤塞栓療法が有効で, arc of Buhler の塞栓が必要 と思われた。症例を報告する。

\section{症例}

症例：61歳, 女性.

主訴：突然の上腹部激痛。

現病歴：2001年 6 月18日夜, 側溝に落ち右背部を打 撲, 肋骨骨折と外傷性肝障害を負い入院となる，3日 後の 6 月 21 日食後突然腹痛を認め, ショック状態と なる。

既往歴：特になし。

現症：右上腹部を中心に筋性防御を認めた。入院後 $140 / 70 \mathrm{mmHg}$ と安定していた血圧は $72 / 50 \mathrm{mmHg}$ と

2001年11月22日受付 2002年 2 月18日採用

〈所属施設住所〉

于623-0066 綾部市駅前通 1
低下した，意識混濁はなし，呼吸困難なし，

経過および検査所見：発症直後の腹部 CT (図 1 a) は，外傷性肝障害の診断目的で撮影した午前中の腹部 $\mathrm{CT}$ (図 1 b) とはまったく異なり，膵頭部に出血性急 性膵炎を疑う高低の不整吸収域を認める。しかし検查 所見では血清および尿アミラーゼ值は正常範囲内で， 急性膵炎ではなく血管性病変による出血を疑った，発 症後血液検査所見では CRP はほほ正常 $(1.6 \mathrm{mg} / \mathrm{dl})$ ， その他血色素 $8.0 \mathrm{~g} / \mathrm{dl}$ ，ヘマトクリット $23.5 \%$ (前日は 各々 $12.5 \mathrm{~g} / \mathrm{dl}, 36.2 \%)$ と出血を疑う所見を示した。 入 院時検查所見も（表 1 ）の如く血清アミラーゼ值は正 常であった.ショック治療を行い，翌日血管造影を施 行した。

$\mathrm{CA}$ 造影 (図 $2 \mathrm{a}$ ) では総肝動脈 (以後 $\mathrm{CHA}$ ), 脾動 脈, 左胃動脈とも造影されたが, $\mathrm{CHA}$ は造影不充分で あった。上腸間膜動脈（以後 SMA）造影 (図 2 b) て は拡張した前後の膵十二指腸動脈（以後 PDA）と $\operatorname{arc}$ of Buhler を経由し CHA が造影されていた. CA 造影 でCHA が不充分な造影となったのはこれら 2 本のシ ヤント血流によるものと思われた。また後膵十二指腸 動脈 (以後 PPDA) 領域に紡鍾状の $25 \mathrm{~mm} \times 8 \mathrm{~mm}$ の大 きな動脈瘤を認めた. 今回この動脈瘤が破裂したもの と思われた，瘤前後動脈は壁不整を示し，動脈瘤破裂 による影響と思われた。 

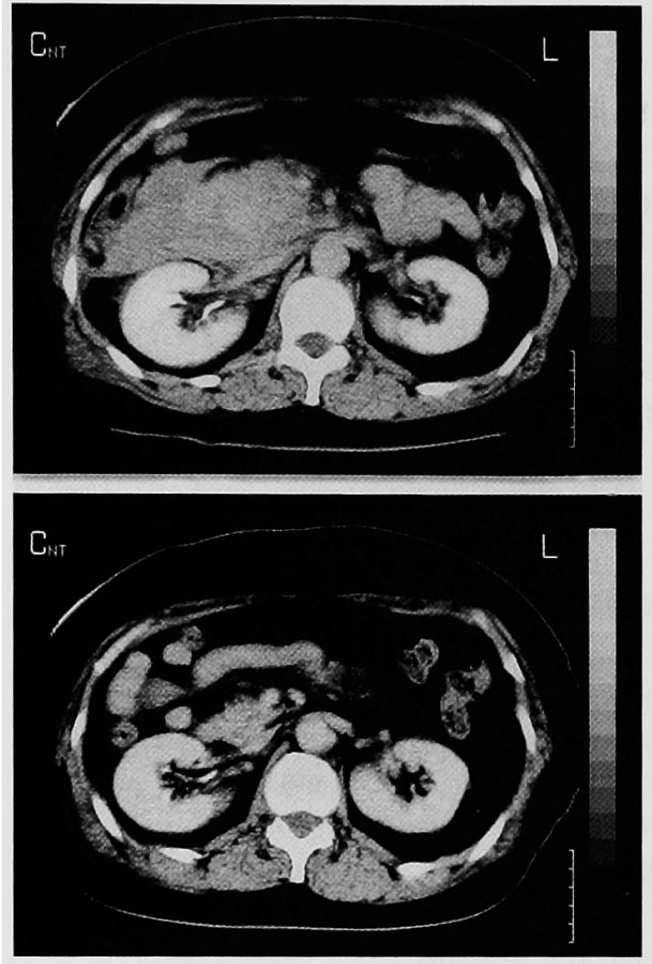

図 $1 \mathrm{a}$ 発症直後の腹部 CT: 脺頭部に拡大した高 低の不正吸収領域を認める。出血性膵炎を思わせ る.

b 発症前午前中の腹部 CT：異常は認めない。 $\frac{\mathrm{a}}{\mathrm{b}}$

表 1 入院時血液生化学検査

\begin{tabular}{lrlr}
\hline $\mathrm{GOT}$ & $122 \mathrm{IU} / 1$ & 白血球 & $8,400 / \mathrm{m}$. \\
$\mathrm{GPT}$ & $106 \mathrm{IU} / 1$ & 赤血球 & $419 万 / \mathrm{m}$. \\
$\mathrm{LDH}$ & $327 \mathrm{IU} / 1$ & 血色素 & $12.8 \mathrm{~g} / \mathrm{dl}$ \\
$\mathrm{ALP}$ & $226 \mathrm{IU} / 1$ & Ht & $37.8 \%$ \\
$\gamma$-GTP & $891 \mathrm{IU} / 1$ & 血小板 & $21.4 万 / \mathrm{m}$. \\
$\mathrm{CHE}$ & $4,858 \mathrm{IU} / 1$ & & \\
$\mathrm{~S}-\mathrm{amy}$ & $77 \mathrm{IU} / 1$ & & \\
$\mathrm{CPK}$ & $138 \mathrm{IU} / 1$ & & \\
$\mathrm{~T}-\mathrm{Bil}$ & $0.7 \mathrm{mg} / \mathrm{dl}$ & & \\
$\mathrm{TP}$ & $6.5 \mathrm{~g} / \mathrm{dl}$ & & \\
$\mathrm{Na}$ & $141 \mathrm{mEq} / \mathrm{dl}$ & & \\
$\mathrm{K}$ & $3.8 \mathrm{mEq} / \mathrm{dl}$ & & \\
$\mathrm{Cl}$ & $103 \mathrm{mEq} / \mathrm{dl}$ & & \\
$\mathrm{Ca}$ & $8.7 \mathrm{mg} / \mathrm{dl}$ & & \\
$\mathrm{P}$ & $3.9 \mathrm{mg} / \mathrm{dl}$ & & \\
$\mathrm{BUN}$ & $15 \mathrm{mg} / \mathrm{dl}$ & & \\
$\mathrm{Cr}$ & $0.6 \mathrm{mg} / \mathrm{dl}$ & & \\
$\mathrm{CRP}$ & $0.6 \mathrm{mg} / \mathrm{dl}$ & & \\
血糖 & $181 \mathrm{mg} / \mathrm{dl}$ & \\
\hline
\end{tabular}
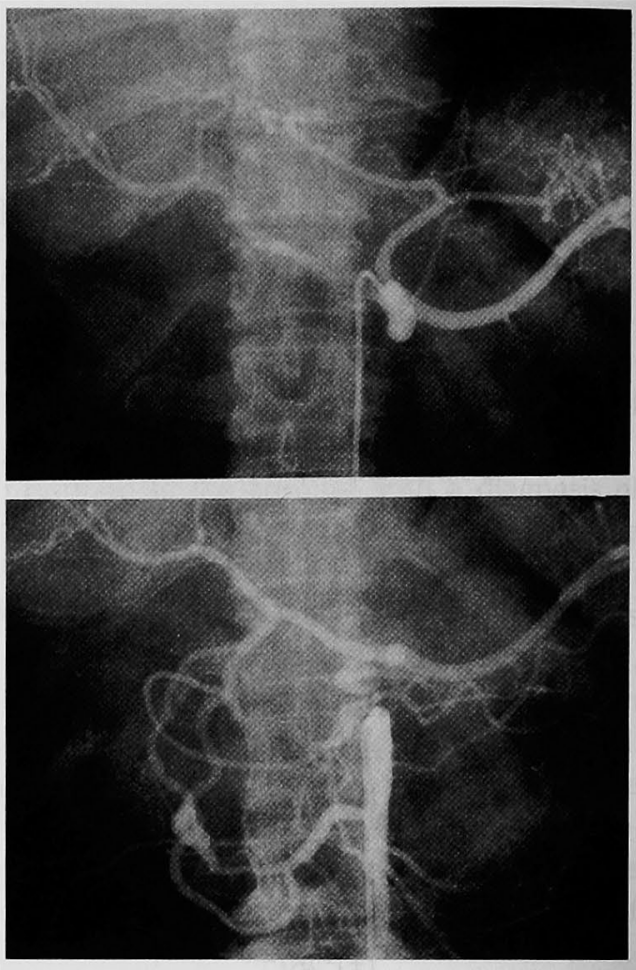

図 $2 \mathrm{a}$ 腹腔動脈造影：総肝動脈の造影が不十分て ある.

b 上腸間膜動脈造影：前後膀十二指腸動脈の 㹡張と, 後膵十二指腸動脈領域に $25 \mathrm{~mm} \times 8 \mathrm{~mm}$ 大の動脈瘤を認める。膵十二指腸動脈や arc of Buhler を通じて上腸間膜動脈から腹腔動脈系へ シャント血流が認められる.

$\frac{a}{b}$

7 月 3 日, 同動脈瘤を SMA, PPDA 経由でコイルに て充填塞栓した。前下脺十二指腸動脈も塞栓した（図 3 ).

7 月18日, SMA 造影にて前後の下膵十二指腸動脈 を交通する新たな動脈瘤（17×7 mm）がみられた (図 $4)$. 前膵十二指腸動脈は塞栓後ほほ正常の太さになっ ていた.

7 月25日, arc of Buhler SMA 側から塞栓した (図 5 ). 瘤の塞栓は失敗した.

8月 8 日, SMA 造影では CA へのシャント血流は 消失していた (図 6 a). 一方, CA 造影では SMAへ のシャント血流は見られない. Arc of Buhler を塞栓 する以前 SMA $>\mathrm{CA}$ の圧較差が存在し, 両動脈系の循 環動態に影響を与えていたことが伺われた。動脈鹰を 㣣み撃ちする目的で SMA 側から下膵十二指腸動脈を 前後分岐部で塞栓した（図 6 b). CA 側からの上前膵 

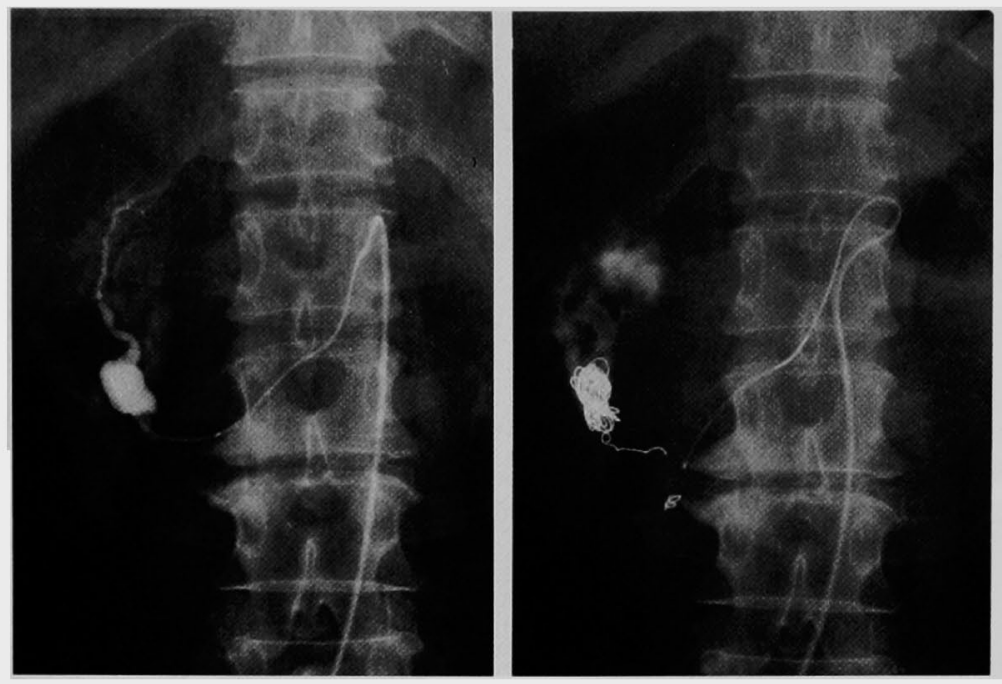

図 3 下膵十二指腸動脈造影 (2001年 7 月 3 日)：上腸間膜動脈を通じて動脈瘤の 充填塞栓と前後膵十二指腸動脈の塞栓を行う.

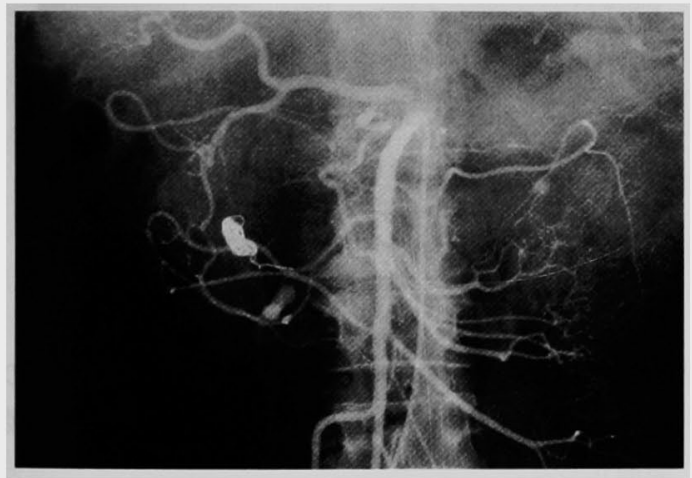

図 4 上腸間膜動脈造影（2001年 7 月18日）：前後脺十 二指腸動脈を跨ぐように新たな動脈瘤を認める、脺十 二指腸動脈は正常の太さに回復している.一方, arc of Buhler を通じて腹腔動脈系が造影されている.

十二指腸動脈の塞栓はうまくいかなかったが，11月 7 日の血管造影では動脈瘤は直径 $2 \mathrm{~mm}$ 大と自然消退し ていた. 経過観察とした。

\section{考察}

PAD-A は比較的珍しい疾患であるが, 報告例が 徐々に増加し, 治療の改善が見られる.PDA-A は, 腹 腔動脈根部での閉塞や狭窄（正中弓状靱帯による圧迫 等も含め) にて PDA が SMA から $\mathrm{CA}$ 系への側副血 行路となることで血流が増大することと動脈の脆弱性 が合わさり発生するとされている. 欧米での PDA-A 報告例の約半数がこの型であるといわれている゙．そ

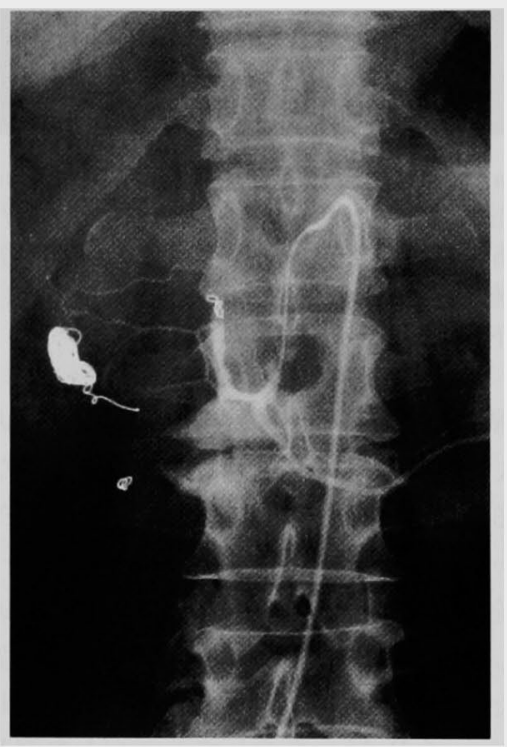

図 5 Arc of Buhler $の$ 塞栓: Arc of Buhler を, SMA を通じて塞栓した。

の他原因として，感染，膵炎，動脈硬化，外傷などが 上げられている，腹腔動脈系閉塞を伴わないPDA-A 症例の報告は少ない.

本症例では急性膵炎の既往や感染などの原因は考え られず，また入院当日の血清アミラーゼが正常である こと，発症当日朝の腹部 CT で膵蔵およびその周囲は 異常を認めないことなどから外傷の可能性も考えに: 

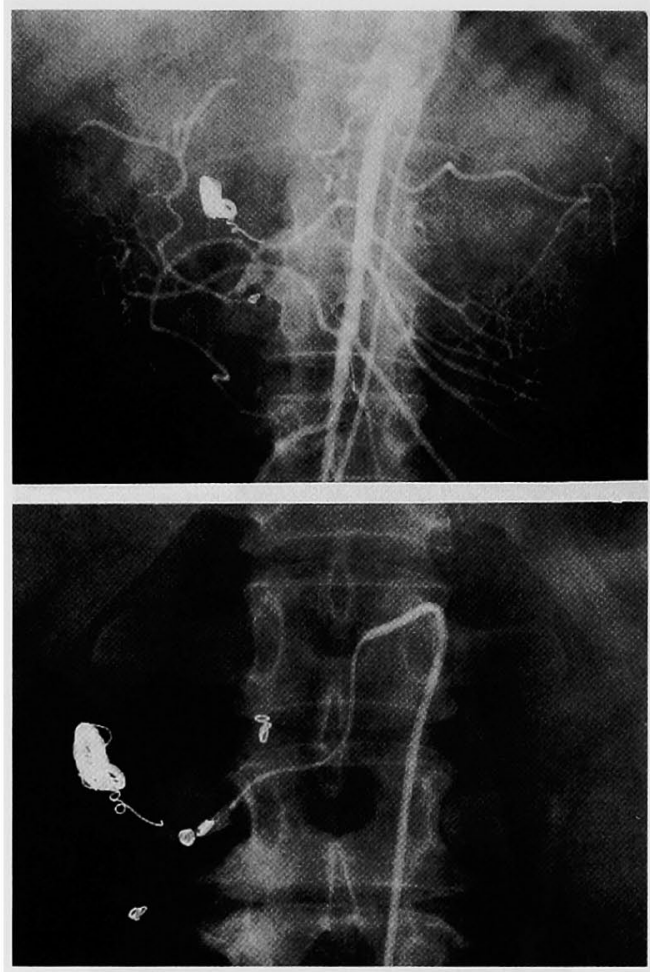

図 6 a 上腸間膜動脈造影：腹腔動脈系への arc of Buhler を通じたシャント血流は消失していた。

b 前後下膵十二指腸動脈の塞栓：動脈瘤への 血流を遮断する目的で，上腸間膜動脈を通じて前 後下膵十二指腸動脈を塞栓した。

い. 血管造影て CA 根部の狭窄や閉塞はないので，本 来 SMA から CA へシャント血流は必要でないと考 えられるが, arc of Buhler, PDA を通じCA 系へ豊 富なシャント血流があるのが確認された。一方 PDA は瘤塞栓後正常と思われる太さに回復し，可逆性の変 化を示した. 後天的に血流の増大が原因で拡張, 動脈 瘤化したことが想定される。瘤塞栓によるPDAの閉 塞後も arc of Buhler を介してシャント血流がみられ た.しかし arc of Buhler の塞栓後は, 腹腔動脈系は CA 造影で良好に造影された。

PDA-A がどのような原因で発生したか， arc of Buhler が先天的に存在していた場合と後天的発生し た場合を分けて考えると，

(1) Arc of Buhler が先天的に存在し, PDA の拡張と瘤 の発生が後天的に生じた. Arc of Buhler を通じた シャント血流によりSMA とCA との間に圧格差が 生じ，この圧格差により PDA 系にも血流の增大が もたらされ，血管拡張と瘤が形成された。
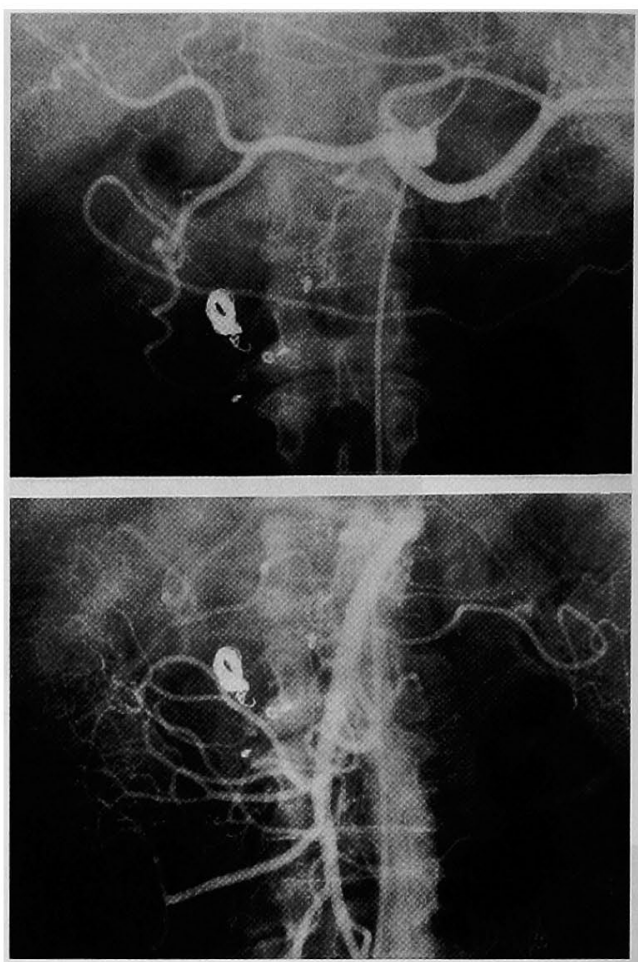

図 7 a 腹腔動脈造影 (2001年11月 7 日)， b 上腸 間膜動脈造影 (2001年11月 7 日)：正常像に近い血 管造影所見を示している.動脈瘤は $2 \mathrm{~mm}$ 大と縮 小している。

(2) Arc of Buhler も後天的に生じた. SMA と CAの 圧格差が生じ，両シャント血管の血流が増大し，動 脈瘤化した。

(2)の場合 (arc of Buhler も PDA も SMA と CA を 結ぶシャント血管であるが), SMA-CA 間に相当の纴 格差が持続的に生じている必要性があり，CA の根部 の狭窄が見られない本症例の場合はこの仮定は想定し にくい. (1)の仮定が想定される.

本症例の如く CA 根部に狭窄や閉塞がない症例では PDA-A の発生に arc of Buhler が大きく関係してい ると考えられる，小野澤ら゙も，PDA-A 破裂による十 二指腸狭窄症例報告の中で腹腔動脈根部閉塞がなく, arc of Buhler または背側膵動脈と考えられるSMA $\rightarrow \mathrm{CA}$ シャント血管の存在を指摘している，瘤成因の 原因は不明としているが， SMA $\rightarrow \mathrm{CA}$ シャントが関 係していると思われる. 小野澤らの報告も本症例も血 流の方向が SMA $\rightarrow \mathrm{CA}$ となっているが, SMA に比 べ CA 系の圧が低い圧格差が本来存在しているのかも しれない. 検索が必要である。 
上記検討より, 治療では疾病治療と血行動態の改善 のためシャント血管と動脈瘤の処理が必要と考えられ 3. 本症例も arc of Buhler, PDA のシャント血管の 塞栓と動脈瘤の塞栓にて最終的に正常に近い安定した 血管画像所見を示した。

Interventional radiology の進歩は本症例の如く末 梢の極めて細い動脈にできた動脈瘤の治療にも大きく 貢献し ${ }^{344)}$, マイクロカテーテルと先端デタッチ型のコ イルなどによる㢞内放り込み塞栓治療や血管の塞栓に よる血流遮断治療は手術に比べ侵熟がなく, 正確に, 余分な血管を障害することなく治療ができるようにな った.

\section{結語}

$\mathrm{CA}$ 根部狭窄や閉塞を伴わない PDA-A 症例を報告 し, arc of Buhler の重要性を中心に考察した。

\section{文 献}

1) Paty PSK, Cordero JA Jr, Darling CR III, et al : Aneurysms of the pancreatico-duodenal artery. J Vasc Surg $23: 710-713,1996$

2）小野澤真弘，西川秀司，高木貴久子他：膵十二指 腸動脈瘤破裂による後腹膜血腫により十二指腸狭 窄を来した 1 例. 日消病会誌 $98: 837-841,2001$

3) Yoneyama F, Tsuchie $K$, Kuno $T$, et al : Aneurysmal rupture of the pancreatico-duodenal artery successfully treated by transcatheter arterial embolization. J Hepato-Bilia-Pancr Surg 5:104-107, 1998

4）森田 穣, 長谷川貴, 花輪 真他：膆十二指腸動 眽瘤に対する経カテーテル動脈塞拴術. IVR $143: 334-342,1999$

\title{
A CASE OF PANCREATICODUODENAL ARTERY ANEURYSM WITHOUT STENOSIS OR OBSTRUCTION OF CELIAC ARTERY
}

\author{
Masaaki TOKURA and Shigeru KAWASAKI \\ Department of Surgery, Ayabe Kyoritsu Hospital
}

Pancreaticoduodenal artery aneurysms are relatively rare. Half of the aneurysms are caused by stenosis or obstruction of the celiac artery except infection, pancreatitis, atherosclerosis and others. It has been thought that much blood flow to the celiac artery from superior mesenteric artery via pancreaticoduodenal artery and weakness of this artery cause aneurysms. We experienced a case of pancreaticoduodenal artery aneurysm without stenosis or obstruction of the celiac artery. Enlarged pancreaticoduodenal artery reduced to normal size after an embolization of the aneurysm and this artery, and a shunt flow to the celiac artery from superior mesenteric artery disappeared after the embolization of the arc of Buhler. From above findings, it is thought that the shunt flow via arc of Buhler increases blood pressure gradient between celiac artery and superior mesenteric artery, and induces dilatation and aneurysm formation by more pressure gradient and much blood flow to the pancreaticoduodenal artery. Embolization of both the arc of Buhler and pancreaticoduodenal artery aneurysm are necessary for treatment. Interventional radiology with a microcatheter is thought to be a non-invasive valuable method. 